（第 1 回）

\title{
IC 化時代における回路設計
}

|||||||||||||||||||||||||||||||||||||||||||||||||||||||||||||||||||||||||||||||||||||||||||||||||||||||||||||||||||||||||||||||||||||||||||||||||||

$\begin{array}{lllll}\text { 日本電気株式会社 川 崎 } & \text { 満 } \\ & & \text { 牛 } & \text { 山 靖 } & -\end{array}$

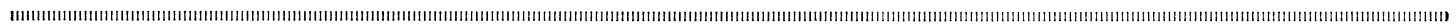

\section{1. ま え がき}

エレクトロニクスの発達によって, 以前には予想でき なかったてとも容易に実現できる時代になってきた。そ して，乙のようなエレクトロニクスの進歩，発展に大き く寄与してきたもののひとつは, トランジスタの発明と IC 化技術の進歩であろう.

そして，いまさらに IC, LSI は Si 技術の進歩に支え られて超 LSI へと指向し，ますます応用分野が広がり 発展して行くことが期待されている.

てのような大きな技術の流れの中にあって，われわれ のテレビジョン技術の分野むその恩恵を受け，日常の回 路設計手法が大きく変化してきている，すなわち，真空 管, トランジスタの時代においては, 装置設計者の主な 仕事は回路設計であったが，IC の時代に入ってそれは 変質しシステム設計的になり，具体的な回路はブラック ボックスとなり，極端な場合は，回路設計を知らなくて あ装置の設計ができるようになった。これは特にディジ タル回路に执いて著しい。

さらに IC 化が進んでモジュール単位の LSI の時代 に入ると，装置設計者の仕事は回路とはほとんど無関係 になり，実装設計が主になるであろう。これは電卓やデ イジタルウオッチの分野ですでに現実のものとなってい る.

このような中で装置設計者に要求される技術には，真 空管, トランジスタの時代とは違ったあのがあると考え られる、設計というあのは本来 Analysis ではなくSynthesis であるから，本講座に打いては，回路の解析には あまり触れずに，回路を構成するための具体的な条件に ついて，それらの新しい技術を含めて解説される予定で ある.

"Applied Solid State and Integrated Circuits; 1. Circuit Design Techniques in ICs Age" by Mitsuru Kawasaki and Yasuichi Ushiyama (Nippon Electric Co., Ltd., Fuchu)

\section{IC 化時代の設計における注意事項}

\subsection{IC 化時代の設計の流れ}

図 1 亿個別部品時代の設計の流れを示すが，従来は新 製品開発の要求に対し，まず設計目標をたて，全体的な 仕様を決め，次にその仕様を細分化して，おの扔のの項 目について細部の具体的な検討を行い，最後にそれらの 細部の検討結果を再びシステム的にまとめ，所期の設計 目標を満足しているか否か判定し，満足している場合は 試作を開始し，不満足の場合は, 細部の設計を再検討す るという方法がとられた。しかし図2 のように IC 化時 代においては，新製品開発の要求汇対し，設計の目標を たてると同時に IC または機能ブロック的なパーッの検 討を行い，それらを組合せた場合の予想特性を推定し，そ れが設計目標と相容れるか否か判断し，相容れない場合 は個別部品による構成やカスタムIC の開発を検討し， 再びそれらを組合せた場合の特性を予想し，満足する場

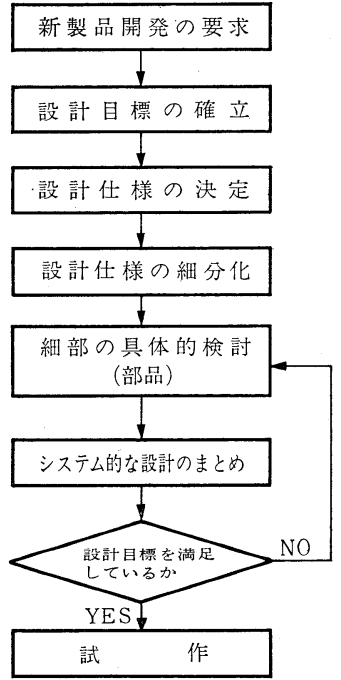

図 1 個別部品時代の設計の流れ 


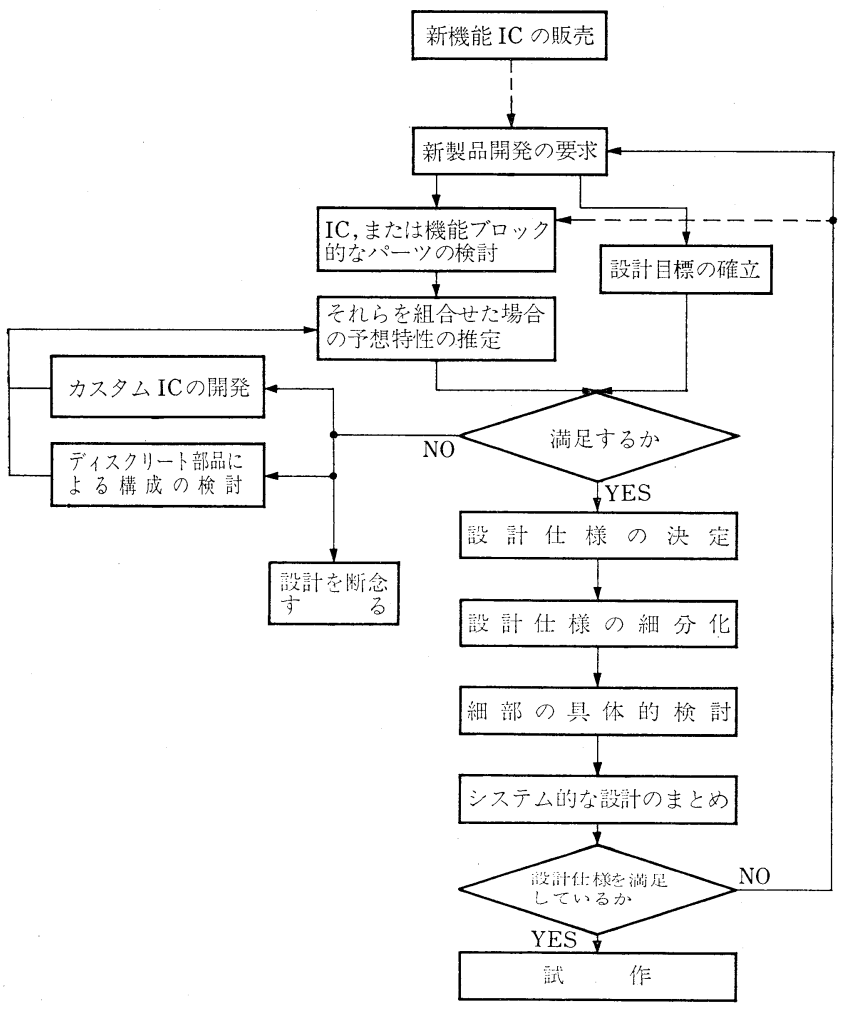

図 2 IC 化時代の設計の流れ

合に設計仕様の決定に入る。また満足しない場合は設計 を断念する場合ああり得る，その後の流れはほとんど図 2 の場合と同じであるが，最終的に仕様を満足している か否かの判断で否と出た場合，それが IC の基本的な特 性による場合は, 要求そのものにもどって検討し直さな ければならない点が異なる，次設計の流れの中で気づ いたてとを述べる。

\section{2 設計目標のたて方 ${ }^{1)}$}

設計とは，仕様を満足する，いくつかの計画の中から 最む有利に実現できる計画を見い出すととで，仕様には 次の 3 つの要素が必要である.
(a) 規格 製品に対する限界条件
(b) 納期
(C) 価格 製造原価抒よび販売価格

この設計において基本仕様の決定が一番重要で, 基本 方針が決まれば設計の $50 \%$ が完了したといっても過言 ではない．基本方針の決定には下記の点の把握が必要で ある。

（a) マーケッティングによる市場動向の把握(価格, 性能, 機能, 開発時期, 商品寿命, セールスポイ ント，他社の動き等)

(b) 過去の自社の実績の完全な把握 (コスト, 性能)

(C) 周囲の技術動向（部品, 方式）
なお，仕様の内容を改善する場合は，近い将 来の目標を現状の半分または 2 倍程度にとり, 実現可能な 1 ステップとして現状の 0.7 倍また は 1.4 倍に目標をおくとよい，改善の項目がコ ストであ机重量または消費電力であれ，3 割程 度の改善が一応世の中で評価され，また新製品 を開発するに足る規準ではないかと考えられ る.

\subsection{IC 化時代における設計者の心がまえ}

（1）広い情報網の確保之利用

設計の流れの項でも述べたように, 新機能 IC の出現は回路設計の基本的な変更をきたすばか りでなく価値の大幅な変更さえ引き起こすとと がある，極端な場合には，新機能 IC の開発自 身が新製品の開発を促すととすらある，例えば 半導体メモリーの出現はビデオ信号の処理に大 きな変革を起こしたし，LSI の出現は電卓の価 格，性能に絶大な影響力を与えたし，マイコン の出現は新しい商品の開発を促した等，枚挙に いとまがない，したがって現在の装置設計者は 特に IC を中心とする機能素子に対し常に広い 情報網を確保し，それらの情報網を整理し必要 に応じて使用できるようにしておくことが大事

である。

(2) 判断力の養成

設計とは，ある限られた制限の中で特性を発揮する素 子を組合せて，ある条件の中で与えられた動作をする回 路を構成するときの判断の集積であるから，判断力の養 成が重要であるととは当然であるが，IC 化時代といえ ども回路を構成するとき必ずしむIC を利用するのが良 いとは限らない，個別部品で構成した方がはるが安価 に小型に構成できるととむ多い.

また現在テレビカメラやVTR 等において，回路の大 規模な IC 化(ハイブリッドまたはモノリシック)2)が行 われているが，どの部分まで IC 化するかというととは IC の歩留り (コスト) と直接関係し, 何が何でも IC 化 するというのはまったく意味がない。

したがって，図了のようにまず当面している回路設計 において一番重要な設計ポイントの抽出を行い，次に個 別部品による回路構成に対し, 市販のIC を利用すると とにより，その点に関し $30 \%$ 以上の改善が可能かぞう か検討し，可能であれば IC を利用する．むし不可能な 場合はカスタム IC の開発による可能性をあたり, 可能 であれば着手し，不可能であれば個別部品を利用して回 路を構成すれば良い。

実際にはポイントを1つに絞り切れないとと, 開発費 


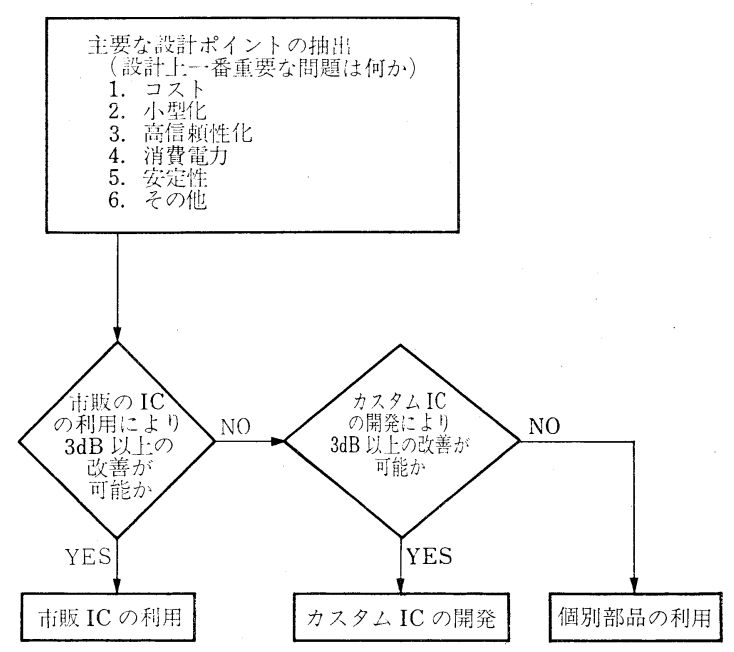

図 3 回路構成の決定

の償却の問題等から $30 \%$ という值を見值す必要がある. この判断が最終的な商品の性能, コス卜と直接結びつい ているため重要である.

\subsection{IC のデータの読み方}

一般的には IC はブラッボックス的な取り扱いになる ため, 回路設計者は IC の中身の詳細については知らな い場合が多く，ほとんどはメ一カーの作成したデータ シートが唯一の頼りになる。したがって，データからど こまで読み取れるかというととが設計者の力を示すとと になる，次にデータシートに書いていないてとが多い項 目で，いくつかの注意点をあげると，

（a）規格上の最大值, 最小值と実際のばらつきの分 布 データシートでは, 最大・最小值をかなり 広くとってあるので, 分布をよく見きわめないと 冗長性の多い設計になってしまう. 数を流すと機 器の特性が安定して来るのは, 折り折りの設計の 補正によりてれらのばらつきに対して自動的に補 正した結果の表われである。

（b）消費電力と放熱 データシートから個々の使 用条件下に打消費電流を算出し, それに対す る適切な放熱設計を検討するのはかなり困難で, 現状ではある程度実際に近い形でシミュレーショ ンする以外にないようである。

（c） $S / N$ OP アンプや差動増幅器を低雑音を必 要とする所に使用する場合は $S / N$ に注意する必 要がある. 電源回路, 偏向回路, ゲインコント ロール回路等がこれに相当する.

\subsection{IC のユニークな使い方}

海外の製品の回路を検討すると, リニア回路にしても ロジック回路にしても非常にユニークな作い方をしてい
る例が数多く見うけられる. それに対して日本のあの は，回路を系統的に簡単にトレースできるがて長な設計 のむのむ多い. 特許等の問題に注意する必要はあるが, できるだけ自分のセクション以外の社内外の情報を整理 分類して使用するとともに, 設計完了前に違った角度か らの検討が必要であろう.

\subsection{IC の選択に関する注意}

\section{(1) セカンドソースの問題}

IC の選択で一番問題になるのはセカンドソースの問 題であろう. IC の場合はトランジスタと違って置き換 えがまったくきかないため，そのIC が万一廃品種に なった場合, ユニットまたは装置そのものが廃品になっ てしまう恐れがある.したがって，原則としてセカンド ソースのある品種を使用すべきである. こうすると同じ 設計に対し安いICを利用したり, 納期的なトラブルを さけられるメリットむある.

万一セカンドソースのない IC を使用する場合は, そ のメーカーの性格, 経営状態, またその IC の開発され た背景をよく調べる必要がある.ヨーロッパのメーカー はこれらの点に特に神経質になっている，例えば RCA にはクロマ処理用の IC として NTSC 用の CA 3126 Q と PAL 用の CA 3128 Q があるが， RCA は NTSC 方 式の国のメーカーであるから NTSC 用の方が生産中止 になる可能性が少ないのではないかとう理由で, 外付部 品が多く必要であるにあかかわらず CA 3126 Q を PAL 用に利用している例がある。

（2）民生用 IC の利用

一般民需用の IC の利点は，何といっても低価格にあ る.したがって，それらを上手に利用したいとてろであ るが，2，3 設計上留意すべき点を述べると，

（a） IC の製品寿命 IC のメーカーは技術革新等 でその IC の需要が減少し探算がとれなくなる と, 一方的に生産の集約を行う恐れがある. しか あ，ほとんどの民生用 IC にはセカンドソースが ない.したがって IC の余命と機器の設計寿命, アフターサービス, 廃品時の処置を検討しておく ことが必要である.

（b）特性の絶対值とばらつき 民需用のIC の特 性が必ずしも放送用に使えるむのではなく、ばら つきむ多い場合がある。

（c）広範な周囲条件下の特性の確保特にきびし い環境条件下での特性については考慮を払ってい ない例が多いので, 確認が必要である.

（3）民生用，通工用，MIL 規格用の IC

一般に同じ品種の IC に対しても, 民生用 IC と通工 用 IC と MIL 規格 IC に分類されている. データシー 
トから見る限り，その差は下記の 3 点にあると思われ る.

(1) 使用温度範囲の広さ

(2) 特性のばらつきと電源に対する余裕度

(3) パッケージ（プラスチック/セラミック）

しかしながらペレット自身は区別して作っているわけ ではないので，その差はもっぱらスクリーニングの差に なっている. これが価格差になって現われ，一般用では 70〜80 円の TTL IC も， MIL 規格品になると 2 桁程 度価格が違うことになる。一般用の IC は通常 $0.2 \%$ 0.5\% 程度の不良率を予期しておかないとだめなよう で，一般用 IC を価格面から使用しなければならない場 合は, 受け入れ時点でのユーザー側の IC のスクリーニ ングが是非必要となる. 小規模の生産の場合は, プリン ト板として組上った段階で行うことも可能であるが，大 規模な生産に対しては IC 自身の事前のスクリーニング が是非必要である. スクリーニングは主に次の3つの方 法によって行う.

(1) 温度サイクル これは低温 $\left(-55^{\circ} \sim-35^{\circ} \mathrm{C}\right)$ と 高温 $\left(125^{\circ} \sim 150^{\circ} \mathrm{C}\right)$ にて各 30 分間位放置するとと を 2 〜 サイクル繰返して熱衝撃を与え, 主にボン ディング関係の不良を発見するためのものである.

(2) 高温放置 $150^{\circ} \sim 175^{\circ} \mathrm{C}$ (ケースがプラスチック かセラミックかによって異なる) で 24〜48 時間位, 窒素ガス中に放置するもので，主にペレット自身の 特性劣化の発見を行う。一般に $15^{\circ} \mathrm{C}$ の温度上昇で 2 倍の加速になるといわれており, $60^{\circ} \mathrm{C}$ で約 16 倍,

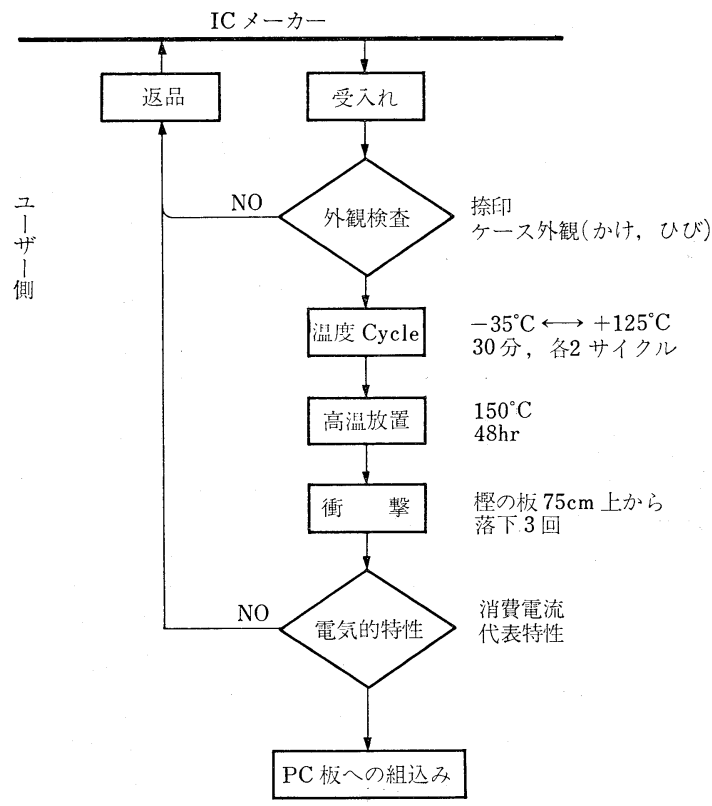

図 4ユニーザーに拉けるIC のスクリーニング $120^{\circ} \mathrm{C}$ では 256 倍の加速試験を行ったことになる.

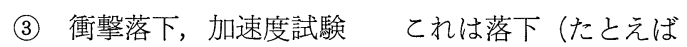
$75 \mathrm{~cm}$ の高さから慗の板へ3 回落下させる)，また 回転により数百 $\mathrm{G}$ 数千 $\mathrm{G}$ 相当の加速度を加えて行 うむので, ボンディング不良, チップのクラックを 発見するために行う.

IC のスクリーニングのフローを図 4 亿示す.

なお，乙こにある電気的特性検査は，いわゆる性能以 外に特に消費電流に注意すべきである. 現在, 電気的に は申し分なく動作していても, 消費電流が規格より多い むのは近い将来故障する可能性が大であるので除去すべ きである.

\section{3. 設計における割り切り方}

良い設計とは，コストパフォーマンスが完全にバラン スがとれた機器を実現することをいう。いいかえれば, 上手に割り切ったものが良い設計というととになる，次 に，いろいろな面からの割り切り方について考えてみ る.

\section{1 価格面}

洒格から割り出した原価, 原価から割り出したパーツ の価格を越えるむのは，例えそれが良いものであっても 一般的には使用できない. したがって特性的に不満が あっても，それを使わざるを得ない場合がある，民生 用，通工用，高信頼度用と分けたとき，パーツの価格は ステップ的に上昇する.

\section{2 最終的な総合目標特性}

例えば, 主特性, 安定性, 信頼性等の特性は, システ ム的に各ブロックのバランスがとれていることが必要で ある. 全体の系を支配する主要な素子の特性に対して周 囲の特性は，それに対してあるマージンをとっておけば 充分である，例えば，

(1) $S / N$ は $10 \mathrm{~dB}$ 以上の差があれば影響をほとん ご与えない.

(2) 周波数特性は $5 \mathrm{MHz}$ の変調度に劣化をきたさ ない程度, すなわち $5 \mathrm{MHz}$ でのレスポンスが $\pm 0.5 \mathrm{~dB}$ 以内であれば良い.

などである。性能を割り切るにしてむ, そこには限度が ある. 一般の放送用機材に対する大まかな特性の検知 限，許容限を知っておくことは設計上必要なととであ る. それらを表 1 にまとめる。乙てらの数值は経験的に 選んだむのむあるが設計上有効な資料となろう.

\section{3 マーケット}

機能の割り切り, 例えば利得調整をローカルに行うに はボリウム 1 個ですむが,リモコンしたい場合は複雑な 可変利得回路が必要になる. したがって, 市場性から判 
表 1 放送機器に括ける各種特性の検知限, 許容值

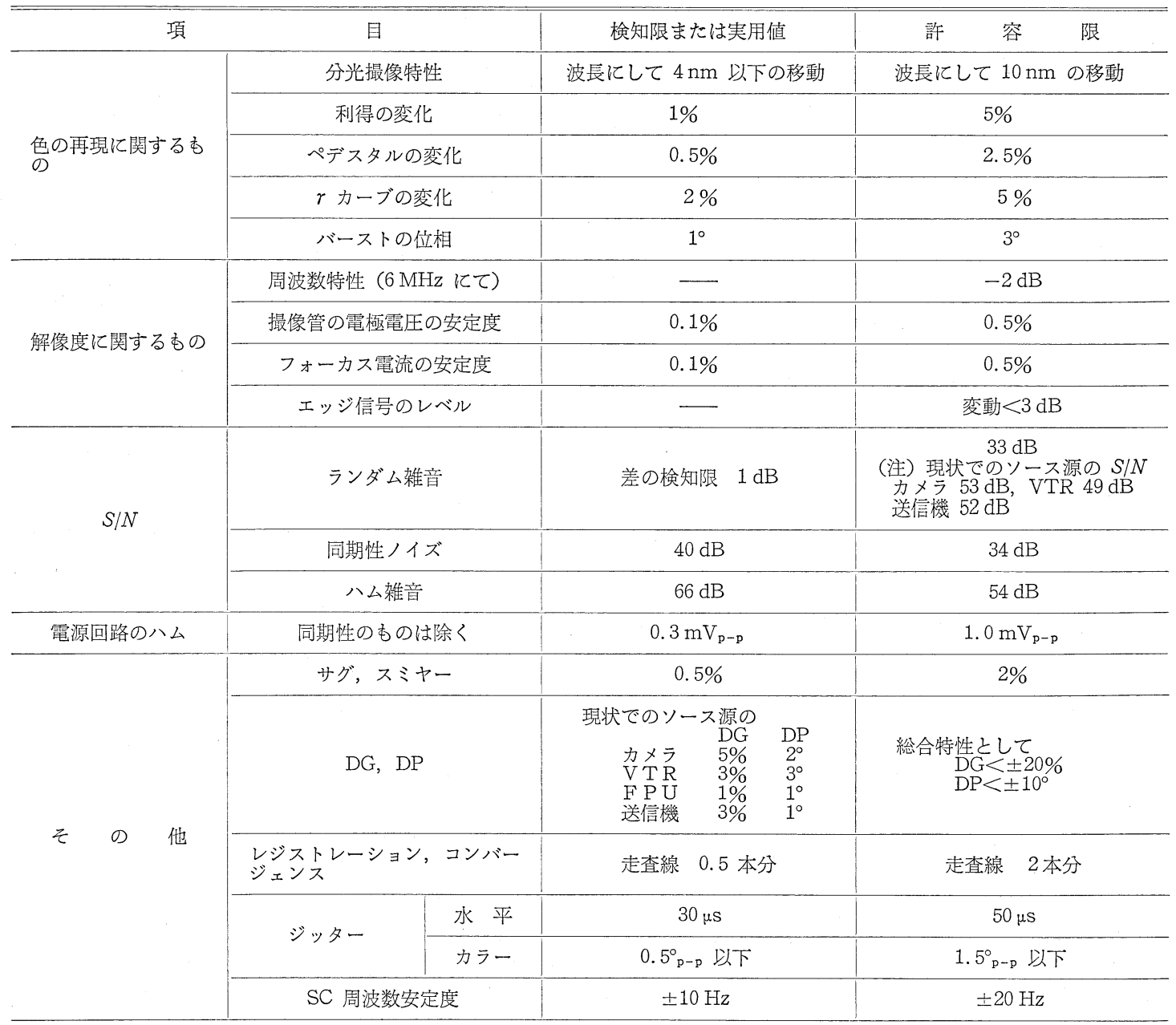

断して不要なりモコン機能は利得調整に限らず，できる だけ除去するのがよい，

同じテレビカメラであ, ITV カメラ, ENG カメラ, スタジオカメラでは，おのずと特性が異なり，それぞれ の用途汇従って性能的な割り切りを行っている.

\section{4 生産性}

生産にあたって一番重要なむのは, ばらつきの少ない ことと，生産のスムーズさであろう。したがって，特性 的には良いが選択しなければ使えないもの，納期的に不 安定なむのは事実上使えない，ただし，それが機器の基 本的な特性を左右する場合は選択むやむを得ないが，価 格は大幅に上昇する. 撮像素子, 受像素子の解像度, ブレミッシュ， $S / N$ を左右する初段素子，分解光学系 の色の再現性, 偏向コイルの走査ひずみ等がこれに相当 し，選別品之無選別品で 1 桁位の価格差がある.

\section{5 時間的制約}

通常，製品の開発には必ず納期が決められているが,
常に間に合うとは限らない。乙のようなとき商品化計画 との兼ね合いで，ある期間内の成果を商品としてま之め る必要むでてくる，てのようなときは，今後の開発改良 のステップを明確にし，製品への対応，市場に出した製 品に対する対応を明らかにして抢く必要がある。

\section{IC 化時代の設計と回路技術者}

IC の一般化に伴って機器の性能は IC の組合せで決 まり,ICさえ同じであれば機器の性能は機器を作るメー カーにはまったく依存しないむのになってくる，さらに IC の集積度が進み，小型化，低消費電力化が実現でき 始めると，実装上の自由度が非常に大きくなってくる. てのように技術的に充足された時代の設計としては，

(1) 素子の独占（特長ある素子の自社開発，独占）

(2) デザイン性または操作性を重視した商品の開発

(3) 大幅なコストダウン

の3つが考えられる．(1)は限られたメーカーしか出来な 
い，(3は生産規模によりほぼ決まってしまうとすると， (2)の項目が設計上重要なウェイトを占めてくる. した がって，乙の時代に扔いては回路設計者といえどあデザ イン的なセンスをみがく必要がある.

\section{5. カスタム IC の開発について}

IC を応用していとうとする場合の考え方の基本は, われわれが取り扱っている電子機器系統の整理と, その IC 化をはかることである.

そして，そのことによって，どのような利点を取りて むことができるかを常に考えて行く必要がある.

IC 化を押し進めることによる主要な利点を考えてみ ると，次のとおりである.

(1) 高信頼性

(2) 高安定性

表 2 半導体 IC 上薄膜・厚膜 IC との比較

\begin{tabular}{|c|c|c|}
\hline & 半導体 IC & 薄膜・厚膜 IC \\
\hline 回路素子 & $\begin{array}{l}\text { 単一材料で } R, C \text { 能動 } \\
\text { 素子が現できき }\end{array}$ & $\begin{array}{l}R, C, L \text { は䒠現し得る } \\
\text { 功能動素子は現ビき } \\
\text { ない }\end{array}$ \\
\hline 使用材料 & $\begin{array}{l}\text { 配線，端子を除いては } \\
\text { 材で林 }\end{array}$ & 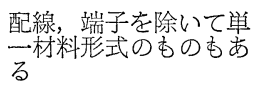 \\
\hline 信 頼 度 & 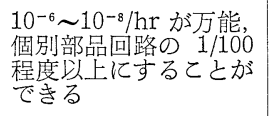 & $\begin{array}{l}10^{-6} \sim 10^{-7} / \mathrm{hr} \text { で,やや } \\
\text { 低い }\end{array}$ \\
\hline 製造原価 & $\begin{array}{l}\text { 量㯆されれれば個別部品 } \\
\text { 回の } 1 / 2 \sim 1 / \text { 路なる }\end{array}$ & 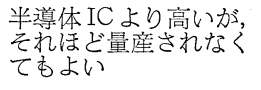 \\
\hline 素子密度 & $10^{4} \sim 10^{5} / \mathrm{cm}^{3}$ & $10^{2} \sim 10^{3} / \mathrm{cm}^{3}$ \\
\hline $\begin{array}{l}R, C, L の \\
\text { 範囲 }\end{array}$ & $\begin{array}{l}R: \text { 数 } 10 \Omega \sim \text { 数 } 10 \mathrm{k} \Omega \\
C: 100 \mathrm{pF}\end{array}$ & $\begin{array}{l}R: 10 \Omega \sim 100 \mathrm{M} \Omega \\
C: \sim 0.1 \mu \mathrm{F} \\
L: \sim 100 \mu \mathrm{H}\end{array}$ \\
\hline $\begin{array}{l}\text { 素子定数の } \\
\text { 㷝差 }\end{array}$ & $\pm 20 \sim 30 \%$ & $\pm 10 \%$ 以下 \\
\hline 温度の影響 & 大きい & 小さい \\
\hline 湿度の影響 & 大きい & 小さい \\
\hline $\begin{array}{l}\text { 素子間干渉 } \\
\text { 员国波 亭 }\end{array}$ & 問題となる & 少ない \\
\hline $\begin{array}{l}\text { 高周波, 高 } \\
\text { 速性 }\end{array}$ & $\begin{array}{l}\text { 素子としては個別部品 } \\
\text { しては適するが, IC }\end{array}$ & 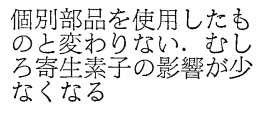 \\
\hline $\begin{array}{lr}\text { 電 } & \text { 力 } \\
\text { 放射線の影 }\end{array}$ & $\begin{array}{l}\text { 数Wまで扱える } \\
\text { 大きい }\end{array}$ & $\begin{array}{l}\text { 数Wまで扱える } \\
\text { 小さい }\end{array}$ \\
\hline 微小電力化 & 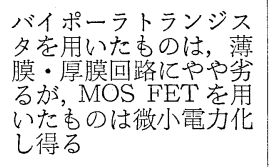 & $\begin{array}{l}\text { 高抵抗を使用, 半導体 } \\
\text { IC より 微小電力化し } \\
\text { 易い }\end{array}$ \\
\hline $\begin{array}{l}\text { 量 産 性 } \\
\text { 回路設計の } \\
\text { 難易 }\end{array}$ & 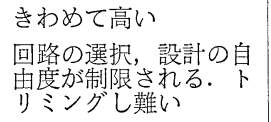 & 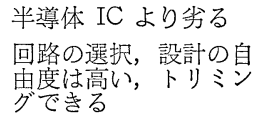 \\
\hline 適応回路 & 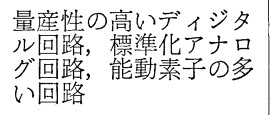 & 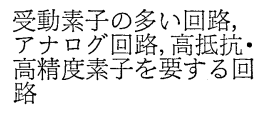 \\
\hline 開 発 費 & 1,000 万円以上 & 数十万円～200万円 \\
\hline
\end{tabular}

(3) 小型・軽量化

(4) 経済性の向上

(5) 機能部品化と使い易さの向上, 省力化

(6) 高周波, 高速性に適した回路構成

IC には，大別して半導体 IC (モノリシック IC), 薄 膜・厚膜 IC（一般には能動素子を合めたハイブリッド IC である) がある. 半導体 IC と薄膜・厚膜 IC との 比較を行ったのが表 2 である.

カスタム IC を開発して行く場合，一般的にいって， 量産化の点ではモノリシック IC の方が有利であるが, 経済性について考えた場合には，どのような回路を IC 化するか，またそのIC 化の程度をどの程度に押える か, という点からの検討が必要である. そこで, 簡単に 両者を比較してみると, 一般に放送技術の分野では受像 機などの一部を除いては数量的な限界から量産効果が得 にくいという問題があり，ハイブリッド IC の方が有利 なととが多い.

また，ハイブリッド IC の場合, 装置設計者が個別部 品で組んだブレッドボードの性能がほぼ $100 \%$ 基板上に 再現できる点が，IC 化你し非常に有利である，モノ リシック IC では寄生容量の問題むあり,ブレッドボー ドでのシミュレーションが非常に困難である.

最後に, 開発納期の点から比較してみると, 厚膜 IC の場合, 最短納期は 4 6 力月, 薄膜 IC の場合 $5 \sim 7$ カ 月，モノリシック IC の場合 10〜18 月月程度かかる. 開発納期は特に製品寿命の短い機器にとっては重要な問 題である. ライフサイクルが比較的短い機器について は，納期の面からハイブリッド IC にメリットがある.

\section{IC 設計者の回路に対する対応と装置 設計者の IC に対する対応}

一般的に IC 回路技術者の設計したビデオ IC は使い にくい. その理由は,

(1) 消費電流が大すぎる（通常 $20 \mathrm{~mA}$ 程度で 1 桁 位大きい)

(2) 利得がありすぎる（通常のビデオ回路は $0 \mathrm{~dB}$ の伝送が多いのに対し $20 \sim 40 \mathrm{~dB}$ 程度ある.女 いぜい $10 \mathrm{~dB}$ あればよい)

(3) 外付部品が多すぎる.

(4) ダイナミックレンジが取れない(通常 $0.7 \mathrm{~V}_{\mathrm{p}-\mathrm{p}}$ に対し少なくとも 3 倍程度必要)

(5) 入カインピーダンスが低すぎる（結合コンデン サが大きくなって不利, 数 $\mathrm{k} \Omega$ 以上必要)

等である、乙れはできるだけ 1 種の IC で多方面に使え るようにとの配慮むあろうが，基本的には装置側の要求 から作られたものでないからであろう．乙の点で両者の 
よりいっそうの接触が望まれる.

装置側としては，今後 IC をいか取り込むかという ことが大きな問題になり, カスタム IC の開発要求が増 すであろう。しかし，IC 側でそれらの要求を満たせる 状況にはないと考えられる。したがって, 装置側として はICのパターン設計まで行う位のととを考える必要が あろう。

ハイブリッド IC については, 付加価值の点からむパ ターン設計からさらに進んで，IC の製造まで検討すべ き場合むある，すなわち，個別部品で組んだときの部品 代とハイブリッド化した IC の洒格は，数量にもよるが 2〜 5 倍程度になる. IC が機能としてまとまって入手 できるので, 組配, 検査工数が低減でき，トータルコス トとしては押えられるが，IC を外注している限り大規 模で IC 化すればするほど社内の付加価值が下るという 問題が発生する.

\section{7.むすび}

最後に，現在装置の開発にたずさわる者として，ICに 関する若干の要望をまとめ，むすびとしたい．

(1) 低電力化 先に述べたように $20 \mathrm{~W}$ 程度の機器 の設計に扔いて $10 \mathrm{~mA}(120 \mathrm{~mW})$ の消費電流は非 常に大きな割合となる，単機能 IC としてはせいぜ い2 3 $\mathrm{mA}$ しか配分できない，例えばビデオ用 IC，オペアンプの低電力化，入出力電位差 $0.5 \mathrm{~V}$ 以 下の低損失シリースレギュレーターなどがこれにあ たる。

(2) 広帯域化 ビデオ回路に使用できるオペアン $7^{\circ}$.

(3) 高スピード化通常のビデオ回路で取り扱うパ
ルスの最高周波数は 4 倍のサブキャリヤ周波数（14 〜 $18 \mathrm{MHz})$ である. この周波数以下で使用できる 低電力ロジック素子.

(4) 高 $S / N$ 現在テレビカメラを初めとする信号 源の $S / N$ は年々改善され，まもなく $60 \mathrm{~dB}$ の時 代を迎えようとしている，乙のために，前述のよう に IC の S/N は少なくとも $70 \mathrm{~dB}$ 以上とってお く必要がある.

(5) 撮像素子の特性 ${ }^{8)}$ 現在 $\mathrm{CCD}$ 等の固体撮像素 子の開発が急ピッチで進められており，現在主に素 子数の向上に努力がそそがれているが，現在の撮像 管のレベルに達するには，かなりの問題を残してい るように思われる。

〔参考文献〕

1) 荒木庸夫：電子機器設計，日刊工業新聞社（昭 45）

2) 牛山ほか：テレビカメラ回路の LSI 化, テレビ学会技 術報告, TBS 49-4 (1978.9)

3）藤森ほか：第 2 世代のカラーテレビ用 MSI (信号系), テレビ学会技術報告, TBS 49-1 (1978.9)

4) 塩谷ほか: 第 2 世代のカラーテレビ用 IC(偏向, 音声), テレビ学会技術報告, TBS 49-2 (1978.9)

5) 大津 浩, 音響機器と厚膜ハイブリッド IC，電子材料， 2 (1979) 73-78

6) 大橋ほか：最近の映像音響機器用半導体デバイス，電子 材料, 2 (1979) 22-26

7）柴田ほか：カラーVTR 用リニア IC, 電子材料, 2(1979) $52-56$

8) Anthony Lind, et al : CCDs in Broadcast Color TV Cameras, Broadcast Engineering, 12 (1978) 47

9) 日本電子機械工業会：電子産業の発展之将来展望，日本 電子機械工業会 (1978.10)

10）電子通信学会東京支部：半導体集積回路技術，電子通信 学会 (1970.3) 